Acta Biologica Plantarum Agriensis 5(1): 42 (2017) ISSN 2061-6716 (Print), 2063-6725 (Online) http://abpa.ektf.hu/
DOI:10.21406/abpa.2017.5.1.42

$4^{\text {th }}$ CC 2017 Abstract

Lecture

\title{
PROTECTED SPECIES OF MACROFUNGI FROM MECSEK AND ZSELIC
}

Védett nagygombafajok a Mecsekből és a Zselicből

\author{
Ágnes RADNÓTI ${ }^{1}$, Lajos BENEDEK² \& Ferenc PÁL-FÁM ${ }^{3}$
}

${ }^{1}$ Cemex Kft, Kapás u 6-12, Budapest; 2Szent István University, Faculty of Horticultural Sciences, Department of Botany and Soroksár Botanical Garden; ${ }^{3}$ Kaposvár University, Institute of Plant Science; e-mail: radnoti.agnes@gmail.com

Fungi fulfill an extremely important role in ecosystems. One of their most significant functions is breaking down organic matter, or forming mycorrhiza with their symbiotic tree partners. There are several factors that contribute to the reclining of the different fungi species, for example the changing or disappearing habitats, like the acidophilus forests, or the decrease of the amount of the substrates, or in the case of edible species, collection. Thus the conservation of the given species and their habitats is necessary.

The legislation of fungi protection in Hungary was established in 2005, when 35 fungi species received legal protection. This list has been extended in 2013, so currently there are 58 fungi species protected by law.

The aim of the current work is to present the protected fungi species that were found in Mecsek and Zselic. The collecting happened mainly in 2016 in the area of Mecsek and Zselic, from acidophilus beech (Fagus) forests and oak and hornbeam (Quercus and Carpinus) forests. The following 6 protected species were found: Ganoderma cupreolaccatum, Hypsizygus ulmarius, Pogonoloma macrocephalum, Grifola frondosa, Scutiger pes-caprae and Volvariella bombycina. Before 2016 other protected species were found as well, Lycoperdon mammiforme, Gyrodon lividus, Sarcodon scabrosus, Hericium erinaceus, Craterellus melanoxeros and Polyporus tuberaster.

The Ganoderma cupreolaccatum prefers the old trees that are characteristic of the oldgrowth woods, since it mainly grows on old beech trunks. It is rare throghout all Europe. It was found in the Kőszegi-forrás forest reserve in the Mecsek, in a hornbeam and oak (Carpinus and Quercus) forest.

Hypsizygus ulmarius is a species that prefers the dead, thicker stumps, especially elm (Ulmus), though it can be found on other deciduous trees as well. It is endangered because the area of the old-growth forests and the adequately thick stumps is declining. Also, the elm disease decimated its preferred substrate. In Mecsek it was found in the Kőszegi-forrás forest reserve.

Pogonoloma macrocephalum grows mainly under old oaks in seminatural oakwoods, that is becoming increasingly rare. Also, this large, edible mushroom may be collected for nutritional purposes. It was found in Mecsek, Kőszegi-forrás forest reserve, and also in the Zselic.

Grifola frondosa lives on the trunks of living oaks (Quercus) or chestnut (Castanea). It was also collected from the Kőszegi-forrás forest reserve.

Scutiger pes-caprae is endangered due to environmental factors: it prefers strongly acidic soil, that are reclining due to eutrophication. It was found in an acidophilus beech forest (Égervölgy, Mecsek).

Volvariella bombycina. This large mushroom grows on old, living or decaying deciduous trees, especially beech and oak. It prefers gallery forests but can also be found in human habitats. The decreasing of old, decaying wood makes it endangered. 